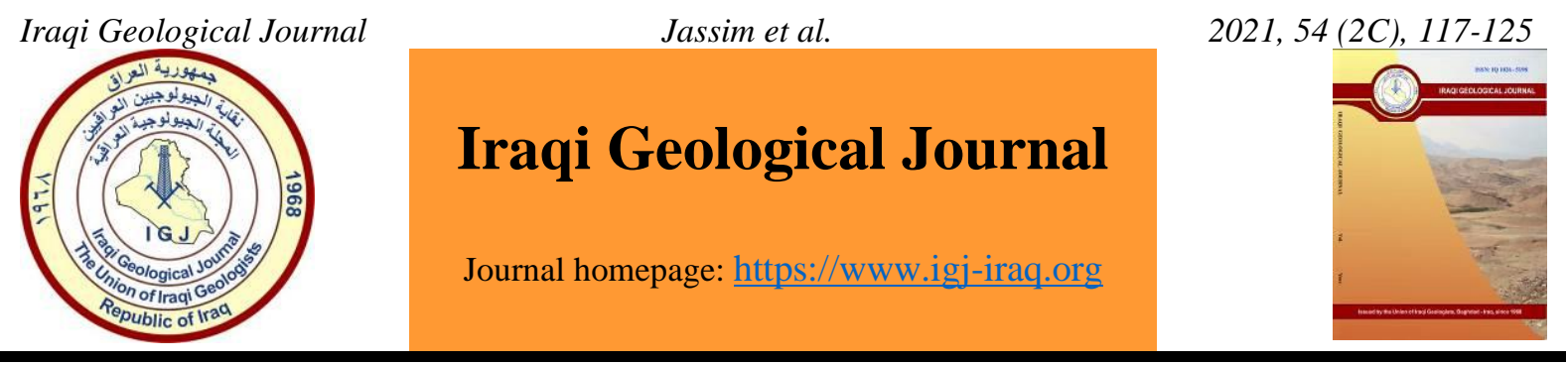

\title{
Sedimentological and Heavy Metals Characteristics of Streets Dust in some Areas East of Baghdad for 2020
}

\author{
Huda Hadi Jassim ${ }^{1}$ *, Ibrahim Mahdi Salman ${ }^{1}$ and Raad Mahmoud Nasif Al-Khafaji ${ }^{1}$ \\ 1 Department of Biology, College of Education for Pure Science (Ibn Al-Haitham), University of Baghdad, Baghdad, Iraq \\ * Correspondence: hudahadi089@gmail.com
}

Received: 14 May 2021; Accepted:5 July 2021; Published: 30 September 2021

\begin{abstract}
Road-side dust samples were collected during August in 2020 from selected areas of, Al-Rusafa, Baghdad, Iraq. A sedimentological and mineralogical analysis of street dust was conducted. Three areas were selected to study street dusts which are Al-Baladitat, Al-Obaidi and Ziona. The laboratory analyses were done in the Department of Geology, College of Science, University of Baghdad. The heavy metal contents were determined in the roadside dust using XRF Method. It was found that the dust is of muddy texture, and is believed to be transmitted with the various storms blowing on Baghdad or by the wheels of Cars. The results of mineralogical investigation revealed that the dust samples composed of quartz, feldspar, calcite, gypsum and sedimentary rocks fragments, as light minerals and the heavy minerals were found as garnet, epidote, chlorites, pyroxene, biotite, zircon, muscovite, hornblende, tourmaline. The heavy metals $(\mathrm{Fe}, \mathrm{Co}, \mathrm{Ni}, \mathrm{Cu}, \mathrm{Zn}$ and $\mathrm{Pb}$ ) in these streets dust samples were studied and used as indicator for pollution. two o main indices are applied: contamination factor, and pollution load index. The contamination factor for $\mathrm{Co}, \mathrm{Zn}, \mathrm{Pb}$, and $\mathrm{Ni}$ is classified as class 2, which indicate moderately contamination, while the contamination factor for $\mathrm{Fe}$ and $\mathrm{Cu}$ is classified as class 1 , which indicate low contamination. The pollution load index values in the all of studied sites are classified as class 2 (Deterioration on site quality) indicating local pollution, as well as denote perfection with class 0 of no pollution.
\end{abstract}

Keywords: Street dust; Heavy metals; Pollution; Baghdad; Iraq

\section{Introduction}

Dust and sand storms are an ongoing problem in Iraq and other areas of the Middle East, almost frequent dust storms and one of the most prominent characteristics of summer in Iraq, raising a large amount of dust (Awadh, 2015). Dust storms are significant phenomena in Baghdad City which represent a serious of natural hazard where the number of days in which dust storms occur is considerable, such phenomenon have a wind speed reach about $5 \mathrm{~m} / \mathrm{sec}$ in July. These storms are most prevalent in spring and summer when a prevailing north westerly wind known locally as the "Shamal "kicks up the fine desert sand and silt along the Tigris and Euphrates rivers basins towards south part of Iraq (Al- Dabbas et al., 2011 and 2012). Moreover, Al-Dabbas et al. (2011) estimated that the texture of dust falls out ranged from sandy clayey silt and clayey sandy silt, whereas the quartz, feldspar, and calcite were most of light minerals, and chlorite, illite, montmorillonite, palygorskite and kaolinite were most of clay minerals in the dust fallout (Awadh, 2012). Soil receives pollutants from a variety of sources including

DOI: $10.46717 /$ igj.54.2C.11Ms-2021-09-30 
automobile exhaust gases, and emissions of factory chimneys, household electric power generators and dust storm. Also, tire friction adds some metals, the motor oils consumed contain heavy metals oil burning, waste incineration. Many researchers who studied soil, water and plants in Baghdad have detected high heavy metals concentration in different sampling media (Khuwaidem, 2007; Habib et al., 2012). In recent years, many studies have focused on the concentration, distribution and source identification of heavy metals in roadside dust (Awadh, 2013). Street dust is typically derived from anthropogenic sources via the interaction of natural solid, liquid or gaseous materials with pollutant sources such as water transported material from surrounding soils and slopes, dry and wet atmospheric deposition, biological inputs, road surface wear, road paint degradation, vehicle wear (tires, body, brake lining, etc.) and vehicular fluid and particulate emissions and discharge from metal processing industries (Al-Khashman, 2004 and 2007; Aydin et al., 2012). The importance of this research lies in the risk pollutants and their impact on the public health. Exposure to heavy metals in road dust can occur by means of ingestion, inhalation and dermal contact. The adverse effects of heavy metals in road dust include respiratory system disorders, nervous system interruptions, endocrine system malfunction, immune system suppression and the risk of cancer in later life (Ferreira- Baptista and Miguel, 2005; Ahmed and Ishiga, 2006). Baghdad as a capital of Iraq has experienced rapid growth in population and urbanization over the last few decades. It is estimated that between 2003 and 2021 a huge number of vehicles were registered. This exerts a heavy pressure on its urban environment. It is situated on the quaternary unconsolidated sediment of the Mesopotamian plain formed mainly from river sediments (sand, silt and clay). The study area is semi-arid to arid climate. The source of heavy elements can be divided into two sources, natural and artificial. Urbanization and industrial processes development and increase extraction of oil and the subsequent burning of associated gas especially during the past years in Baghdad city, these exerts formed a heavy pressure on its urban environment. For these reasons it is necessary to know the main sedimentological and mineralogical characteristics of the street dust in Baghdad. This work was carried out on roadside dust in nine selected sites of the city of Baghdad (Fig. 1) (Al-Jaberi and Al-Dabbas, 2014).

The city of Baghdad is characterized by the lack of afforestation and green areas, especially after the migration of the population and the increase density of the population in it, which made the city vulnerable to the impact of wind gusts carrying with it particles of soil and spread dust and suspended particles depending on the source of dust that is transmitted with the wind gusts, as the civil generators, factories and car exhausts increase the concentration of these particles suspension in the air.

Air Pollution means the presence of any solid, liquid or gaseous substances that lead to physiological, economic and biological damage to humans, animals and plants (Kabata-Pendias and Mukherjee, 2007), street dust is an important source in the generation and release of dust particles into the atmosphere through the movement of vehicles as it constitutes a percentage (33\%) of air pollutants. Therefore, the quantity of street dust and the quality of its contents are evidence of the environmental pollution in large cities and a source of air pollutants (Kabata-Pendias and Mukherjee, 2007, Lu et al., 2009; Awadh and Ahmed, 2013), where the texture of street dust consists of solids suspended have different sizes either transmitted with dust storms and whose components are deposited during the end of the storm or these materials are originally from the various human activities transmitted with winds and deposited on the sidewalks. The aim of the research is to investigate the sedimentological and mineralogical characteristics and the possible pollution by using the contamination factor (CF), and Pollution load index (PLI) of the street dust in Al-Rusafa, eastern Baghdad that has negative effects on the environment and human health. 


\section{Study area}

The study area is located in eastern Baghdad and the eastern outskirts of Baghdad on the side of Al-Rusafa, where three areas were selected to study street dust: Al-Baladitat, Al-Obaidi and Ziona (Fig. 1). Baghdad is Iraq's largest city and the second largest Arab capital after Cairo with its density of population. It is divided in half by the Tigris River, the Karkh and Rusafa. The climate of the region is characterized by the desert climate with very hot summer, (The Iraqi Ministry of Transport, 2011).
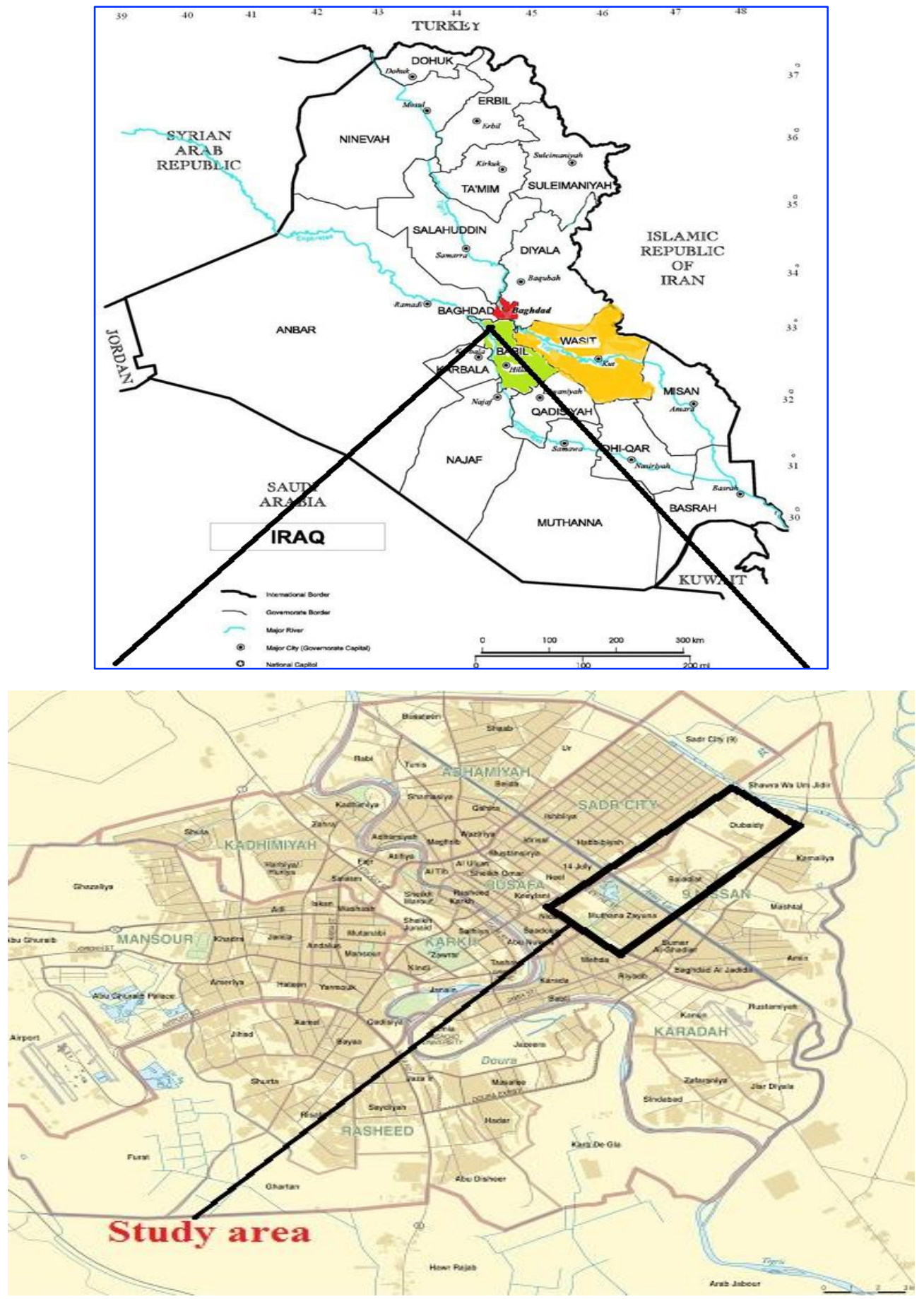

Fig.1. The study area 


\section{Materials and Methods}

Total of nine road dust samples were collected during 2020, three from each of the studied locations: Al-Baladitat, Al-Obaidi and Ziona at the eastern part of Baghdad (Al-Rusafa) (Fig. 1). The collected samples were carefully transferred to the plastic bags using small brushes and then were brought to the laboratory under the same conditions. All samples were transferred to the laboratory of geochemistry in the Department of Geology, University of Baghdad for sedimentological, mineralogical and XRF Method analyses. Light and heavy minerals were studied by polarized microscope as well after applying the grain size method following folk 1974 procedure. The results are tabulated in Table 1 and Fig. 2.

Table 1. Volumetric analysis of the study area samples according to Folk (1974)

\begin{tabular}{llccc}
\hline No. of samples & Type of texture & Clay\% & Silt \% & Sand \% \\
\hline A1=1 Ziona & Clayey silt (Mud) & 35.6 & 55.7 & 8.7 \\
A2=2 Ziona & Clayey silt (Mud) & 35.9 & 54.3 & 9.8 \\
A3=3 Ziona & Clayey silt (Mud) & 40.5 & 50.4 & 9.1 \\
C1=4 Al-Obaidi & Clayey silt (Mud) & 44.7 & 47.8 & 7.5 \\
C2=5 Al-Obaidi & Clayey silt (Mud) & 37.6 & 53.5 & 8.9 \\
C3=6 Al-Obaidi & Clayey silt (Mud) & 38.8 & 51.4 & 9.8 \\
B1=7 Al-Baladitat & Clayey silt (Mud) & 34.0 & 58.4 & 7.6 \\
B2=8 Al-Baladitat & Clayey silt (Mud) & 31.9 & 58.3 & 9.8 \\
B3=9 Al-Baladitat & Clayey silt (Mud) & 29.1 & 62.7 & 8.2 \\
Average\% & Clayey silt (Mud) & 36.45 & 54.72 & 8.82 \\
\hline
\end{tabular}

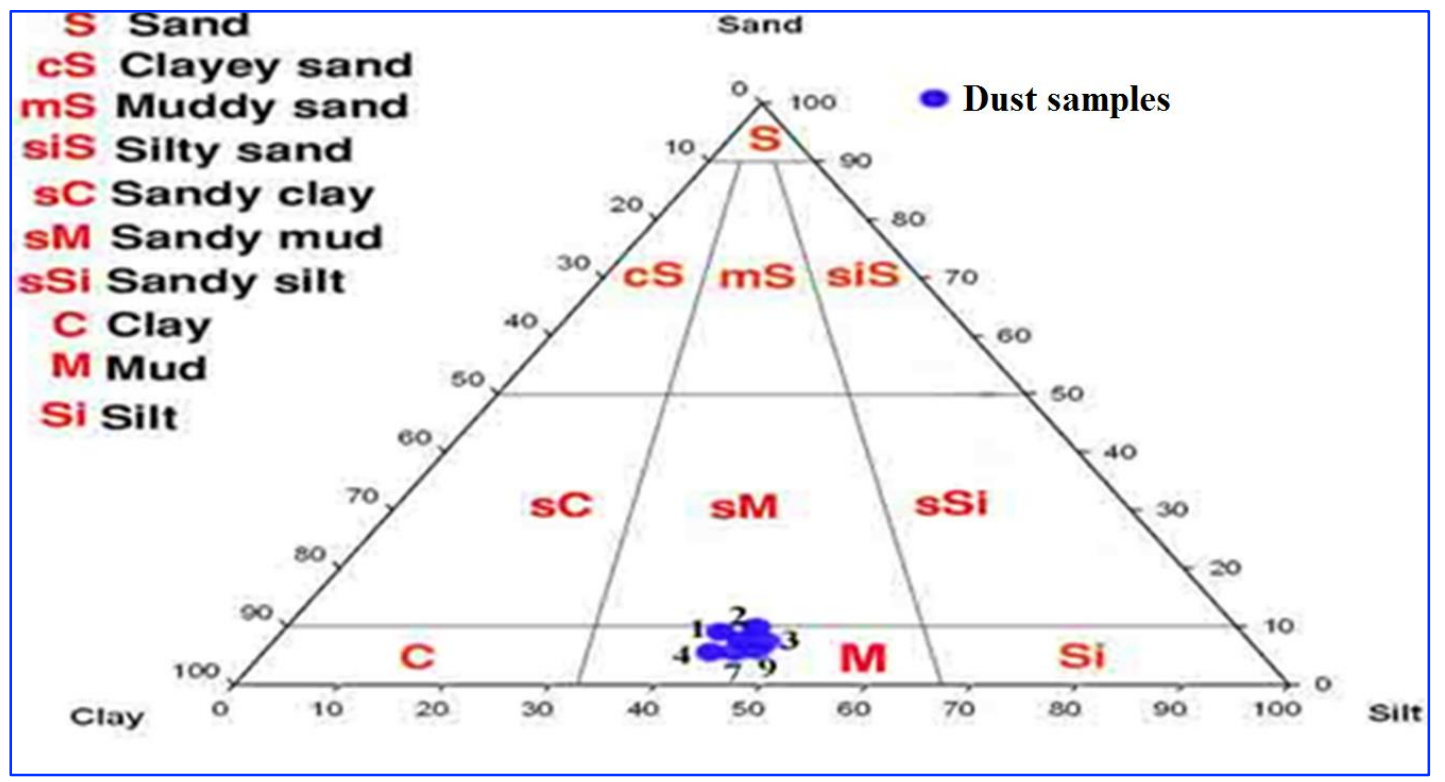

Fig. 2. Texture classification for dust particles according to Folk (1974)

Minerals were diagnosed and their percentages are determined by the point count method and by the method proposed by Fleet (1926) (Table 2). A group of metals have been identified as part of the installation of dust particles in the German-Iraqi laboratory in the Department of Geology, College of Science, University of Baghdad. 
Table 2. Percentage of heavy minerals to light minerals in the sediments

\begin{tabular}{lccccc}
\hline Samples & $\begin{array}{c}\text { Weight of } \\
\text { sample } \mathbf{( g m )}\end{array}$ & $\begin{array}{c}\text { Weight of } \\
\text { light minerals } \\
(\mathbf{g m})\end{array}$ & $\begin{array}{c}\text { Percentage of } \\
\text { light minerals } \\
(\boldsymbol{\%})\end{array}$ & $\begin{array}{c}\text { Weight of } \\
\text { heavy } \\
\text { minerals }(\mathbf{g m})\end{array}$ & $\begin{array}{c}\text { Percentage of } \\
\text { heavy minerals } \\
\mathbf{\%}\end{array}$ \\
\hline A2 & 5 & 4.93 & 98.6 & 0.07 & 1.4 \\
A3 & 5 & 4.94 & 98.8 & 0.06 & 1.2 \\
C1 & 5 & 4.87 & 97.4 & 0.13 & 2.6 \\
C2 & 5 & 4.89 & 97.8 & 0.11 & 2.2 \\
B1 & 5 & 4.91 & 98.2 & 0.09 & 1.8 \\
B3 & 5 & 4.95 & 99.0 & 0.05 & 1.0 \\
\hline
\end{tabular}

\subsection{Light Components}

Light components were identified and their percentages determined by the point count method and by the method proposed by Fleet (1926). A group of metals have been identified within the composition of dust particles and as: quartz, feldspar (Orthoclase Plagioclase minerals), gypsum, calcite, sedimentary rocks Fragments.

\subsection{Heavy Minerals}

Minerals were diagnosed and their percentages determined by the point count method and by the method proposed by Fleet (1926). A group of metals have been identified with relatively high percentages within the composition of dust minutes as garnet, epidote, chlorites, pyroxene, biotite, zircon, muscovite, hornblende, tourmaline and opaques. The opaque metals consist mainly of iron oxides, the highest percentage among heavy metals in the degree of very soft sand in all samples by a ratio and are generally under a microscope appearing in an angular-to-angular similar form and some semicircular rounded grains.

\subsection{Trace Elements}

The detection of the trace elements $\mathrm{Fe}, \mathrm{Co}, \mathrm{Zn}, \mathrm{Cu}, \mathrm{Ni}$, and $\mathrm{Pb}$ was done by using the XRF Method, the results obtained from the grain size analysis are clay, silt and sand by applying the absorbent method as in the following table

Table 3. Values of heavy metals for the streets dust samples within Al-Rusafa, Baghdad

\begin{tabular}{ccccccc}
\hline Sample No. & $\mathbf{F e}_{2} \mathbf{O}_{\mathbf{3}} \mathbf{\%}$ & $\mathbf{C o} \mathbf{~ p p m}$ & $\mathbf{Z n ~ p p m}$ & $\mathbf{C u} \mathbf{~ p p m}$ & $\mathbf{N i} \mathbf{~ p p m}$ & $\mathbf{P b} \mathbf{p p m}$ \\
\hline A1 & 2.35 & 17.9 & 151.3 & 162.5 & 61 & 94.5 \\
A2 & 2.02 & 3.9 & 103.6 & 25.1 & 52.2 & 38.9 \\
A3 & 1.48 & 11.4 & 65.7 & 19.4 & 41.5 & 18.1 \\
B1 & 3.1 & 18.4 & 166.6 & 161.1 & 52.1 & 34.9 \\
B2 & 1.96 & 10.6 & 104.1 & 35.7 & 47.6 & 26.7 \\
B3 & 1.28 & 11.7 & 111.1 & 18.4 & 32.3 & 13.6 \\
C1 & 2.11 & 17 & 129 & 39.8 & 53.3 & 52.5 \\
C2 & 2.34 & 3.9 & 184.5 & 63.7 & 66.9 & 64.3 \\
C3 & 2.03 & 3.9 & 149.9 & 38.5 & 57.9 & 23.1 \\
Ml-Dabbas et al., 2018 & 2.19 & 10.97 & 129.5 & 62.7 & 51.7 & 40.7 \\
\hline
\end{tabular}

The concentrations of heavy metals ( $\mathrm{Fe}, \mathrm{Zn}, \mathrm{Cu}, \mathrm{Co}, \mathrm{Pb}$, and $\mathrm{Ni}$ ) and assessment of heavy metals pollution in the streets dust particles of Baghdad by using the contamination factor (CF), and Pollution load index (PLI) as an attempt to evaluate the heavy metals pollution in the streets dust samples particles in Baghdad city-southern Iraq. 


\section{Results and Discussion}

In order for understanding the factors that influences the dust samples composition, it is essential to analysis the dust texture, mineralogy and trace elements content covering the study area where dust sampling was carried out.

\subsection{Sedimentological Analysis}

The results of grain size analysis of dust samples of Al-Baladitat, Al-Obaidi and Ziona at the eastern part of Baghdad (Al-Rusafa) show that the silt and clay are a major part where the silt average $(54.72 \%)$, ranging between $47.8 \%-62.70 \%$, Clay comes in the second rank in terms of the relative distribution with an average of $36.45 \%$, it ranges between $29.10 \%-44.7 \%$, and sand average $(8.82 \%)$, ranges between $7.5 \%-9.8 \%$, (Table 1). While, the samples nomenclature indicated that all the samples are nominated as mud according to Folk (1974) (Fig. 2).

\subsection{Mineralogy Study by Microscope}

Heavy minerals are minerals of parent rock destruction by weathering and abrasion, and that have a specific gravity greater than 2.85 (Pettijohn, 1975). Heavy minerals are important constituents of sandstones; most sands contain a small (1-2\%). A group of metals have been identified with relatively high percentages within the composition of dust samples such as garnet, epidote, chlorites, pyroxene, biotite, zircon, muscovite, hornblende, tourmaline and opaques.

\subsection{X-Ray Fluorescence Analysis (XRF)}

Metals, a major category of globally-distributed pollutants, are natural elements that have been extracted from the earth and harnessed for human industry and products for millennia. Metals have overall potential to be toxic even at relatively minor levels of exposure. Exposure to metals can occur through a variety of routes. Metals may be inhaled as dust or fume (tiny particulate matter, such as the lead oxide particles) (Howard $\mathrm{Hu}, 2002$ ). The source of heavy elements can be divided into two sources, natural and artificial. The sources of heavy metals in dust storms are mainly natural; include geologic sources such as rocks formation, soils and transported sediments by winds and dust storms, while the artificial sources include industrial sources that supply the heavy metals to the air and causing contamination of the atmosphere (Al-Dabbas et al., 2011). Six common heavy metals are discussed in this research: iron, cobalt, zinc, copper, lead, and nickel in the dust particles of the studied area (Table 3). The averages concentrations of $\mathrm{Pb}$ in dust particles of Al-Baladitat, Al-Obaidi and Ziona sites ranging from $13.6 \mathrm{ppm}$ in site No. B3 to $94.5 \mathrm{ppm}$ in site No. A1 with mean value of $40.7 \mathrm{ppm}$ and the values of $\mathrm{Cu}$ in dust particles ranging from $18.4 \mathrm{ppm}$ in site No. B3 to $162.5 \mathrm{ppm}$ in site No. A112 with mean value of $62.7 \mathrm{ppm}$. While, the averages concentrations of Fe in dust particles ranging from $1.28 \%$ in site No. B3 to $3.1 \%$ in site No. B1 with mean value of $2.19 \%$ and the averages concentrations of $\mathrm{Zn}$ in dust particles are ranging from $65.7 \mathrm{ppm}$ in site No. A3 to $184.5 \mathrm{ppm}$ in site No. C2 with mean value of 129.5 $\mathrm{ppm}$. The amount of $\mathrm{Ni}$ in dust particles are ranging from $41.5 \mathrm{ppm}$ in site No. A3 to $66.9 \mathrm{ppm}$ in site No. C2 with mean value of $51.7 \mathrm{ppm}$, while, the averages concentrations of Cobalt $(\mathrm{Co})$ in dust particles ranging from3.9 ppm in 10 sites to $18.4 \mathrm{ppm}$ in site No. B1with mean value of $10.97 \mathrm{ppm}$. Observed from the concentrations of heavy metals in the dust particles of studied sites (Table 3 ) that significantly increase of these metals in some sites, this increase may be due to urbanization and industrial processes problems, represented by manufacturing, waste flaring associated gas from oil drilling sites, and from vehicle emission. Comparing the above results with the averages of Al-Dabbas et al. (2018), reflect that they are lower for $\mathrm{Fe}, \mathrm{Ni}$ and $\mathrm{Pb}$ and higher for $\mathrm{Co}, \mathrm{Zn}$ and $\mathrm{Cu}$ average values. 


\subsubsection{Contamination Factor $(\mathrm{CF})$}

Contamination factor (CF) was determined following equation according to Thomilson et al. (1980). The level of contamination by metals was established by applying the CF that can be calculated as follows:

$\mathrm{CF}=\mathrm{Cm}$ Sample/ Cm Background (Tables 4 and 5).

$\mathrm{Cm}$ Sample $=$ the heavy metals concentration in the sediments and

$\mathrm{Cm}$ Background= the geochemical background concentration of the heavy metals (crustal average) (Muller,1969; Taylor and McLennan, 1985; Lu et al., 2009).

The contamination factor (CF) for $\mathrm{Fe}, \mathrm{Co}, \mathrm{Zn}, \mathrm{Cu}, \mathrm{Ni}$, and $\mathrm{Pb}$ was calculated in Table 4. Lead (Pb) classified as class 2 representing moderate contamination ranging from 1.33 to 2.82 for samples A3, B1, $\mathrm{B} 2, \mathrm{~B} 3$, and $\mathrm{C} 3$. While other samples classified as class 3 representing considerable contamination in four samples (No. A1, A2, C1 and C2) ranging from 3.17 to 5.78. The CF for Ni classified as class 2 which indicate moderately contamination in all the studied sites, ranging from 1.00 to 1.13. It is believed that considerable part of Lead and nickel find their way into the environment as a result of the burning of diesel oil and oil spilling that caused to increase both of nickel in the sediments. The $\mathrm{CF}$ for $\mathrm{Cu}$ classified as class 1 which indicate low contamination ranging from 0.42 to 0.80 , except three sites (No. A1, B1and C2) have 2.91, 2.91 and 1.46 respectively, classified as class 2 representing moderate contamination. It is believed that considerable part of copper finds its way into the environment as a result of the burning of diesel oil and may be due to the disposal of copper-containing wastewater. Zinc ( $\mathrm{Zn}$ ) classified as class 2 representing moderate contamination ranging from 1.14 to 2.71 . $\mathrm{Zn}$ is come from toxic waste from industrial sources (Thorpe and Harrison, 2008). Cobalt (Co) classified as class 1 representing a low contamination ranging from 0.16 to 0.72 . The $\mathrm{CF}$ for $\mathrm{Fe}$ classified as class 1 which indicates low contamination, ranging from 0.70 to 0.95 except one site (No. B1) classified as class 2 which indicate moderate contamination. It is believed that considerable part of iron finds its way into the environment as a result of the burning of diesel oil and may be due to the disposal of iron -containing wastewater.

\subsubsection{Pollution Load Index (PLI):}

The PLI provides a simple but comparative means for assessing a site quality. Pollution load index (PLI) was determined following equation according to Thomlison et al. (1980), where PLI is expressed as follows:

$\mathrm{PLI}=\mathrm{n} \sqrt{\mathrm{CF}} 1 \times \mathrm{CF} 2 \times \mathrm{CF} 3 \times \ldots . . \times \mathrm{CFn}$, Where:

$\mathrm{n}=$ the number of studied metals in each site.

The Pollution Load Index (PLI) for $\mathrm{Fe}, \mathrm{Co}, \mathrm{Zn}, \mathrm{Cu}, \mathrm{Ni}$, and $\mathrm{Pb}$ was calculated and classified as class 0 with perfection of no pollution, while three sites (B2, C1, and C3) were classified as class 2 (Deterioration on site quality) indicating local pollution, ranging from 1.09 to 1.46.

Table 5. Classified grades of CF and PLI indices, (after Thomilson et al., 1980)

\begin{tabular}{lc}
\hline CF contamination factor & PLI \\
\hline$<1$ & Perfection (class 0) \\
$<1$ Low contamination & $=$ 1 Baseline \\
$($ class 1$)$. & Level (class 1). \\
$1 \leq \mathrm{CF}<3$ Moderate contamination & $>1$ Deterioration \\
$($ class 2$)$. & on site quality (class 2) \\
$3 \leq \mathrm{CF} \leq 6$ Considerable & Contamination (class 3) \\
$>6$ Very high & Contamination (class 4) \\
\hline
\end{tabular}




\section{Conclusions}

The results of grain size analysis of dust samples of Al-Baladitat, Al-Obaidi and Ziona at the eastern part of Baghdad (Al-Rusafa) show that the silt and clay are a major part. The samples nomenclature indicated that all the samples are nominated as mud according to Folk, 1974. The dust samples are composed of quartz (both monocrystalline and polycrystalline) with an average of $30.6 \%$, feldspar (microcline feldspar, orthoclase feldspar and plagioclase) with an average of 17.2\%, and mainly sedimentary rock fragments with less percentages of igneous, and metamorphic rock fragments, with an average of $52.1 \%$, the sedimentary rock fragments (carbonates, and chert), evaporate and other clay (coated clay). The relatively high percentage heavy minerals are identified. these are garnet, epidote, chlorites, pyroxene, biotite, zircon, muscovite, hornblende, tourmaline and opaques. The heavy metals $(\mathrm{Fe}, \mathrm{Co}, \mathrm{Ni}, \mathrm{Cu}, \mathrm{Zn}$ and $\mathrm{Pb}$ ) in the streets dust samples were studied and used as indicator for pollution by using two o main indices: contamination factor (CF), and pollution load index (PLI). The contamination factor for $\mathrm{Co}, \mathrm{Zn}, \mathrm{Pb}$, and $\mathrm{Ni}$ classified as class 2, which indicate moderately contamination, while the contamination factor for $\mathrm{Fe}$ and $\mathrm{Cu}$ classified as class 1, which indicate low contamination. PLI values in the all of studied sites classified as class 2 (Deterioration on site quality) indicating local pollution, as well as denote perfection with (class 0 ) of no pollution. In conclusion, it is believed that the dust samples of Al-Obaidi are with relatively higher local pollution than Al-Baladitat and Ziona street dust samples. In general, the distribution pattern of the concentrations of metals was affected essentially by exhausted gases emitted from transportation automobile as well as the direction of the prevailing wind played a major role in the transport of the pollutants.

\section{Acknowledgements}

The authors are very grateful to the Editor in Chief Prof. Dr. Salih M. Awadh, the Secretary of Journal Mr. Samir R. Hijab. and the Technical Editors for their great efforts and valuable comments.

\section{References}

Ahmed, F., Ishiga, H., 2006. Trace metal concentrations in street dusts of Dhaka city, Bangladesh, Atmospheric Environment, 40, 3835-3844.

Al-Dabbas, M., Abbas, M., Al-Khafaji, R. 2012. Dust storms loads analyses, Iraq, Arabian Journal Geoscience., $5,121-131$.

Al-Dabbas, M., Abbas, M., and Al-Khafaji, R., 2011.The mineralogical and micro-organisms effects of regional dust storms over Middle East Region. International Journal Water Resources, 1, 2, 129-141.

Al-Dabbas, M.A., Mahdi, K.H., Al- Khafaji, R., Obayes, K.H., 2018. Heavy metals characteristics of settled particles of streets dust from Diwaniyah City- Qadisiyah Governorate - Southern Iraq, Journal of Physics, $1003,012023$.

Al-Jaberi, M. H., \& Al-Dabbas, M. A., (2014). Assessment of heavy metals pollution in the sediments of Iraqi coastlines. Science, 3(9).

Al-Khashman, O. A., 2007. The investigation of metal concentrations in street dust samples in Aqaba city, Jordan, Environmental Geochemical Health, 29, 197-207.

Al-Khashman, O.A., 2004. Heavy metal distribution in dust, street dust and soils from the work place in Karak Industrial Estate, Jordan, Atmospheric Environment, 38, 6803-6812.

Awadh, S.M. and Ahmed, R.M., 2013. Hydrochemistry and pollution probability of selected sites along the Euphrates River, Western Iraq. Arabian Journal of geosciences, 6(7), 2501-2518.

Awadh, S.M. and Ahmed, R.M., 2013. Hydrochemistry and pollution probability of selected sites along the Euphrates River, Western Iraq. Arabian Journal of geosciences, 6(7), 2501-2518.

Awadh, S.M., 2012. Geochemistry and mineralogical composition of the airborne particles of sand dunes and dust storms settled in Iraq and their environmental impacts. Environmental Earth Sciences, 66(8), 2247-2256. 
Awadh, S.M., 2013. Assessment of the potential pollution of cadmium, nickel and lead in the road-side dust in the Karkh district of Baghdad City and along the highway between Ramadi and Rutba, Western Iraq, Journal of Environmental Science and Toxicology, 1(7), $126-135$.

Awadh, S.M., 2015. Cd, Ni, and Pb distribution and pollution assessment in roadside dust from Baghdad City and Western Iraqi Desert. Arabian Journal of Geosciences, 8(1), pp.315-323.

Aydin, F., Aydin, I., Erdogan, S., Akba, O., Isik, B., Hamamci, C., 2012. Chemical characteristics of settled particles during a dust- storm. Pollution Journal Environment Studies, 21(3), 33-537.

Ferreira-Baptista, L., de Miguel, E.D., 2005. Geochemistry and risk assessment of street dust in Luanda, Angola: A tropical urban environment. Atmospheric Environment, 9, 4501-45312.

Fleet, W. F. 1926. Petrological notes on the red sandstone of the West Midlands. Geological Magazine, 63, 505516.

Folk, R. 1974. Petrology of Sedimentary Rocks. Hamphill, Texas, 182pp.

Habib, H.R., Awadh, S.M. and Muslim, M.Z., 2012. Toxic heavy metals in soil and some plants in Baghdad, Iraq. Al-Nahrain Journal of Science, 15(2), 1-16.

Howard Hu, M.D. 2002. Human health and heavy metals exposure. In: Life Support: The Environment and Human Health, Michael McCally (ed), MIT press.

Kabata-Pendias, A., Mukherjee, A. B., 2007. Trace Elements from Soil to Human. Springer-Verlag Berlin Heidelberg, 561.

Iraqi Ministry of Transport, 2011. General Authority for Meteorology and Seismic Monitoring. Information about the study map, Baghdad.

Khwedim, K.H., Al-Anssari, H.R., Al- Bassam K., 2009. Study of distribution of some heavy metals in the soil of Basra city- south of Iraq, Iraqi Journal Science, 50, 4, 533-542.

Lu, X.L., Wang, K., Lei, J.H., Zhai, Y., 2009. Contamination assessment of copper, lead, zinc, manganese and nickel in street dust of Baoji, NW China, Journal Hazardous, 161, 1058-1062.

Muller, G. 1969. Index of geoaccumulation in sediments of the Rhine River, Journal Geology2, 108-118.

Nolan, K., 2003. Copper toxicity syndrome, Journal Orthomol. Psychiatry, 12, 4, 270 - 282.

Pettijohn, F. J. 1975. Sedimentary Petrology, An Introduction. Blackwell Scientific publication, Oxford, 252 pp.

Taylor, S.R., McLennan, S.M., 1985. The continental crust: its composition and evolution, Blackwell, Oxford.

Thorpe, A., Harrison, R.M. 2008. Sources and properties of non-exhaust particulate matter from road traffic: A review. Science of Total Environment., 400 (1-3), 270-282.

Tomlinson, D. L., Wilson, J. G., Harris, C. R., \& Jeffrey, D. W., 1980. Problems in the assessment of heavy-metal levels in estuaries and the formation of a pollution index. Helgoländer meeresuntersuchungen, 33(1-4), 566-575. 